\title{
CARACTERIZAÇÃO MORFOLÓGICA DO FRUTO, DA SEMENTE E DO DESENVOLVIMENTO DA PLÂNTULA DE Blepharocalyx salicifolius (H.B.K.) Berg. E Myrceugenia gertii Landrum - MYRTACEAE ${ }^{1}$
}

\author{
SUELEN SANTOS REGO², ANTONIO CARLOS NOGUEIRA ${ }^{3}$, YOSHIKO SAITO KUNIYOSHI ${ }^{4}$, \\ ÁLVARO FIGUEREDO DOS SANTOS ${ }^{5}$
}

\begin{abstract}
RESUMO - O objetivo neste trabalho foi caracterizar morfologicamente os frutos, as sementes e o desenvolvimento da plântula de Blepharocalyx salicifolius e Myrceugenia gertii. Para descrever os frutos e sementes foram utilizadas 100 unidades e para a descrição do desenvolvimento da plântula foram colocadas para germinar 100 sementes em substrato papel toalha, à temperatura de $25{ }^{\circ} \mathrm{C}$ e 50 sementes em substrato vermiculita. Os frutos de B. salicifolius e M. gertii são carnosos e indeiscentes do tipo bacóide. As sementes de B. salicifolius possuem forma de espiral, coloração castanha semitransparente, não possuem endosperma e o embrião é do tipo pimentóide. As sementes de $M$. gertii são ovaladas, de coloração castanha semitransparente, comprimidas lateralmente, o endosperma é mucilaginoso e o embrião é do tipo mircióide. A germinação de ambas é epígea fanerocotiledonar.
\end{abstract}

Termos para indexação: morfologia vegetal, Myrtaceae, sementes florestais.

\section{MORPHOLOGICAL CHARACTERIZATION OF THE FRUIT, THE SEED AND SEEDLING \\ DEVELOPMENT OF Blepharocalyx salicifolius (HBK) Berg. AND Myrceugenia gertii \\ Landrum - MYRTACEAE}

\begin{abstract}
The objective of this study was to morphologically characterize the fruits, seeds and developing seedlings of Blepharocalyx salicifolius and Myrceugenia gertii. One hundred fruits and seeds were used for the morphological description and to follow seedling development, 100 seeds were placed in a paper towel substrate at a temperature of $25^{\circ} \mathrm{C}$ and 50 seeds in vermiculite. The fruits of $B$. salicifolius and $M$. gertii are fleshy and indehiscent and of the bacoideus type. The seeds of $B$. salicifolius have a spiral shape, are a brown transparent color, have no endosperm and the embryo is of the pimentoid type. The seeds of $M$. gertii are oval, have a transparent brown color, are laterally compressed with a mucilaginous endosperm and the embryo is of the myrcioid type. The germination of both is epigeous phanerocotyledonal.
\end{abstract}

Index terms: plant morphology; Myrtaceae; seed forest.

\footnotetext{
${ }^{1}$ Submetido em 20/08/2009. Aceito para publicação em 10/05/2010. Parte da Dissertação de Mestrado do primeiro autor apresentada a UFPR (Universidade Federal do Paraná).

${ }^{2}$ Bióloga, Pós graduanda do Programa de Pós Graduação em Engenharia Florestal, UFPR, suelen_srego@yahoo.com.br, bolsista REUNI.
}

CEP: 80210-170. Curitiba, nogueira@ufpr.br.

${ }^{4}$ Naturalista, Dra., Professora Sênior, Dep. de Ciências Florestais, UFPR, yoshiko@ufpr.br.

${ }^{5}$ Eng. Agr., Dr., Pesquisador, Embrapa Florestas, Caixa postal: 319, CEP. 83411-000.Colombo, alvaro@cnpf.embrapa.br.

${ }^{3}$ Eng. Flor., Dr., Professor Associado II, Dep. de Ciências Florestais, UFPR, 


\section{INTRODUÇÃO}

A grande dificuldade para estudos de estrutura, fenologia e comportamento de uma espécie dentro de uma comunidade é a sua identificação correta, pois em determinadas circunstâncias, têm-se apenas o fruto, a semente ou a plântula para o reconhecimento das espécies. A partir de conhecimentos sobre as estruturas da semente podem-se obter indicações sobre germinação, armazenamento, viabilidade e métodos de semeadura. Para a botânica sistemática, que se baseia no maior número de caracteres para comparação, o estudo morfológico da semente e da plântula consiste em mais um elemento de identificação (Kuniyoshi, 1983). Além da unidade de dispersão é imprescindível um melhor conhecimento da germinação, do crescimento e do estabelecimento da plântula para compreender o ciclo biológico e a regeneração natural da espécie (Oliveira, 1993).

Para a família Myrtaceae, a morfologia de frutos, sementes e plântulas torna-se ainda mais necessário, principalmente para as características do embrião, pois os embriões desta família são de grande importância taxonômica e tem servido de base para a classificação das Myrtaceae em tribos (Barroso, 1984; Barroso et al., 1999; Landrum e Kawasaki, 1997). De acordo com Barroso (1984) as espécies americanas de Myrtaceae assemelhamse muito na maioria dos caracteres, tornando-se muito difícil o trabalho de identificá-las e classificá-las.

A tribo Myrteae é dividida em três subtribos, distintas pela morfologia do embrião: Myrtinae, caracterizada pelo hipocótilo desenvolvido e cotilédones pequenos ou vestigiais; Mirciinae, cotilédones foliáceos e hipocótilo desenvolvido; e Eugeniinae, cujos cotilédones são carnosos e o hipocótilo é vestigial ou ausente (Morais e Lombardi, 2006; Landrum e Kawasaki, 1997). Barroso et al. (1999) classificam estes tipos de embriões como: embrião mircióide, embrião pimentóide e embrião eugenióide. No entanto, Barroso (1984) descreve, além destes três tipos de embriões, mais cinco tipos especializados: embrião mirceugenóide, característico de espécies de Myrceugenia; embrião plinióide, observado em Plinia e Neomitranthes; embrião de transição entre os tipos plinióide e eugenióide, característico de sementes de Myrcianthes sp.; embrião relacionado com os tipos mircióide e pimentóide característico de Feijoa sellowiana e uma forma especializada do embrião pimentóide, encontrado em Campomanesia e Blepharocalyx.

Apesar da importância dos estudos sobre a morfologia de frutos, sementes, germinação e plântulas de Myrtaceae, na literatura existem poucos trabalhos sobre espécies florestais nativas pertencentes a esta família. Dentre estes trabalhos pode-se citar o de Santos et al. (2004) que descreveram os tipos de frutos e a germinação de Acca sellowiana, Campomanesia guazumifolia, Campomanesia xanthocarpa, Eugenia rostrifolia, Myrcianthes pungens e Psidium cattleyanum; e Kuniyoshi (1983) e Amorim (1996) que dentre outras espécies caracterizaram morfologicamente os frutos, sementes, germinação e plântulas de Myrcia arborescens e Syzygium jambolanum, respectivamente.

Blepharocalyx salicifolius conhecida popularmente como murta, é uma árvore de pequeno porte até grande (4 a $30 \mathrm{~m}$ ) de tronco geralmente reto podendo chegar a 40 cm de DAP (Carvalho, 2006; Lorenzi, 1998; Marchiori e Sobral, 1997; Silva Júnior, 2005; Landrum, 1986). Sua distribuição natural ocorre na Floresta Estacional Decidual, Floresta Estacional Semidecidual, Floresta Ombrófila Densa, Floresta Ombrófila Mista, Restinga, Cerrado e nos Campos. Considerada uma espécie secundária tardia ou clímax exigente de luz (Carvalho, 2006) desenvolve-se nos mais variados ambientes ou estágios da vegetação, desde campos até sub-bosques desenvolvidos. É frequente nas florestas ciliares (Lorenzi, 1998), e sem dúvida é uma das mirtáceas mais expressivas na Floresta Ombrófila Mista, em remanescentes que já se encontram em estágios mais desenvolvidos (Legrand e Klein, 1978). Pode ser aproveitada para o paisagismo (Lorenzi, 1998) e para plantios ao longo das margens de rios, por ocorrer naturalmente nestes ambientes e por atrair aves dispersoras de sementes (Carvalho, 2006; Silva Júnior, 2005).

Myrceugenia gertii é uma espécie arbórea, geralmente de pequeno porte, podendo chegar até $7 \mathrm{~m}$ de altura. (Landrum, 1981; Legrand e Klein, 1970; Morais e Lombardi, 2006). O nome desta espécie, como muitas outras, homenageia o botânico brasileiro Dr. Gert Hatschbach (Landrum, 1984). A sua distribuição ainda não é muito conhecida, porém dados na literatura relatam a ocorrência da espécie no estado do Paraná nos municípios de Bocaiúva do Sul, Campina Grande do Sul, Piraquara e São José dos Pinhais, e em São Paulo no município de Jacupiranga (Landrum, 1984). Está na lista vermelha de plantas ameaçadas de extinção, na categoria em perigo no Paraná e vulnerável na lista de São Paulo (Paraná, 1995; FAPESP, 2006), apesar disto não existem informações na literatura sobre a ecologia e características silviculturais 
da espécie.

Desta forma objetivou-se com este trabalho caracterizar morfologicamente os frutos, sementes e o desenvolvimento da plântula de $B$. salicifolius e $M$. gertii, devido à importância ecológica das espécies e a disponibilidade de frutos no momento da coleta.

\section{MATERIAL E MÉTODOS}

Os frutos de B. salicifolius foram coletados de 12 matrizes localizadas no município de Colombo - PR, no mês de março de 2007, e os frutos de $M$. gertii foram coletados de 12 matrizes localizadas nos municípios de Bocaiúva do Sul e Campina Grande do Sul - PR no mês de maio de 2006. Foram coletadas amostras do material vegetal de $B$. salicifolius e $M$. gertii e confeccionadas exsicatas que receberam a numeração 10187 e 10104, respectivamente e depositadas no Herbário Escola de Florestas de Curitiba (EFC) do Departamento de Engenharia Florestal da Universidade Federal do Paraná.

A extração das sementes foi realizada através da maceração e lavagem dos frutos em água corrente, tomando-se o cuidado para não danificar as sementes, pois estas são frágeis devido ao seu tegumento membranáceo. Posteriormente as sementes foram deixadas secar a sombra durante 24 horas, sendo que as danificadas foram descartadas.

Caracterização morfológica do fruto e da semente: Foram utilizadas 100 sementes e 100 frutos aleatoriamente para descrever e ilustrar morfologicamente os frutos e as sementes. As observações foram feitas através de microscópio estereoscópico e a olho nu. Foram anotadas as medidas de comprimento, largura e espessura, com auxílio de um paquímetro e expressas em milímetros, e calculados o desvio padrão e o coeficiente de variação.

Para a descrição da morfologia dos frutos foi observado o tipo de fruto, as características do epicarpo, tais como: textura, pilosidade, coloração, brilho e forma; número de sementes por fruto e deiscência; e do mesocarpo: consistência e coloração. Das camadas do pericarpo puderam ser diferenciadas de forma arbitrária apenas o epicarpo (camada externa) e o mesocarpo (camada interna), sendo que o endocarpo não pode ser diferenciado sob microscópio estereoscópico, pois segundo Souza (2006) a delimitação dessas regiões pericárpicas nem sempre é fácil.

Nas sementes, foram feitas secções transversais e longitudinais e analisados as seguintes características: cor, textura, consistência, forma, posição do hilo e da micrópila, presença ou ausência de endosperma, e se presente o tipo e a cor. O tipo, a posição e a forma do embrião, a forma e consistência dos cotilédones e a posição do eixo hipocótilo-radícula.

As características morfológicas relevantes do fruto e da semente foram ilustradas e descritas, tendo sido consultados como base para a classificação os trabalhos de Barroso et al., (1999), Kuniyoshi (1983), Spjut (1994) e Souza (2006).

Caracterização morfológica do desenvolvimento da plântula: Para o acompanhamento do desenvolvimento da plântula foram colocadas para germinar 100 sementes em gerbox, contendo três folhas de papel toalha umedecidos com água, destilada em germinador regulado a temperatura de $25{ }^{\circ} \mathrm{C}$, e semeadas 50 sementes em bandejas de plástico contendo o substrato vermiculita. Foram realizadas ilustrações das fases, desde a emissão da radícula até o desenvolvimento dos protofilos. $\mathrm{Na}$ caracterização morfológica da plântula foram analisadas características da raiz: o tipo, a forma e a coloração; do hipocótilo e epicótilo: a pilosidade, a forma e a coloração; dos cotilédones e protofilos: a consistência, a textura, a forma, a nervação, a coloração e o tipo de bordo, ápice e base, conforme Vidal e Vidal (2003) e Roderjan (1983). A plântula estabelecida foi considerada quando os protofilos já estavam totalmente expandidos (Roderjan, 1983).

O material utilizado para a descrição da morfologia foi conservado em álcool $70 \%$ e depositado no Laboratório de Sementes Florestais da Universidade Federal do Paraná.

\section{RESULTADOS E DISCUSSÃO}

\section{Blepharocalyx salicifolius}

Fruto: de acordo com Barroso (1984) e Barroso et al. (1999) as Myrtaceae Sul-Americanas, com exceção do gênero Tepualia, indígena do Chile, estão subordinadas à Tribo Myrteae, que se caracterizam pelos frutos carnosos e indeiscentes do tipo bacóide, um fruto simples carnoso, proveniente de ovário súpero, uni a pluricarpelar, uni a plurispérmico, sendo o pericarpo não diferenciado internamente por um endocarpo endurecido (Souza, 2006; Spjut, 1994). Os frutos de B. salicifolius (Figura 1-A, B) são glabros, de forma globosa, possuem cálice marcescente (Figura 1-B), que segundo Souza, 2006 pode permanecer durante todo o desenvolvimento do fruto até a sua fase 
madura, de 1 a 3 sementes por fruto e em média $5,29 \mathrm{~mm}$ de comprimento e $5,49 \mathrm{~mm}$ de diâmetro (Tabela 1). O epicarpo tem pouca espessura, é liso, possui coloração verde, amarela, laranja e vermelha, e glândulas por toda a superfície (Figuras 1-C, D). O mesocarpo tem coloração laranja, é semitransparente e carnoso.
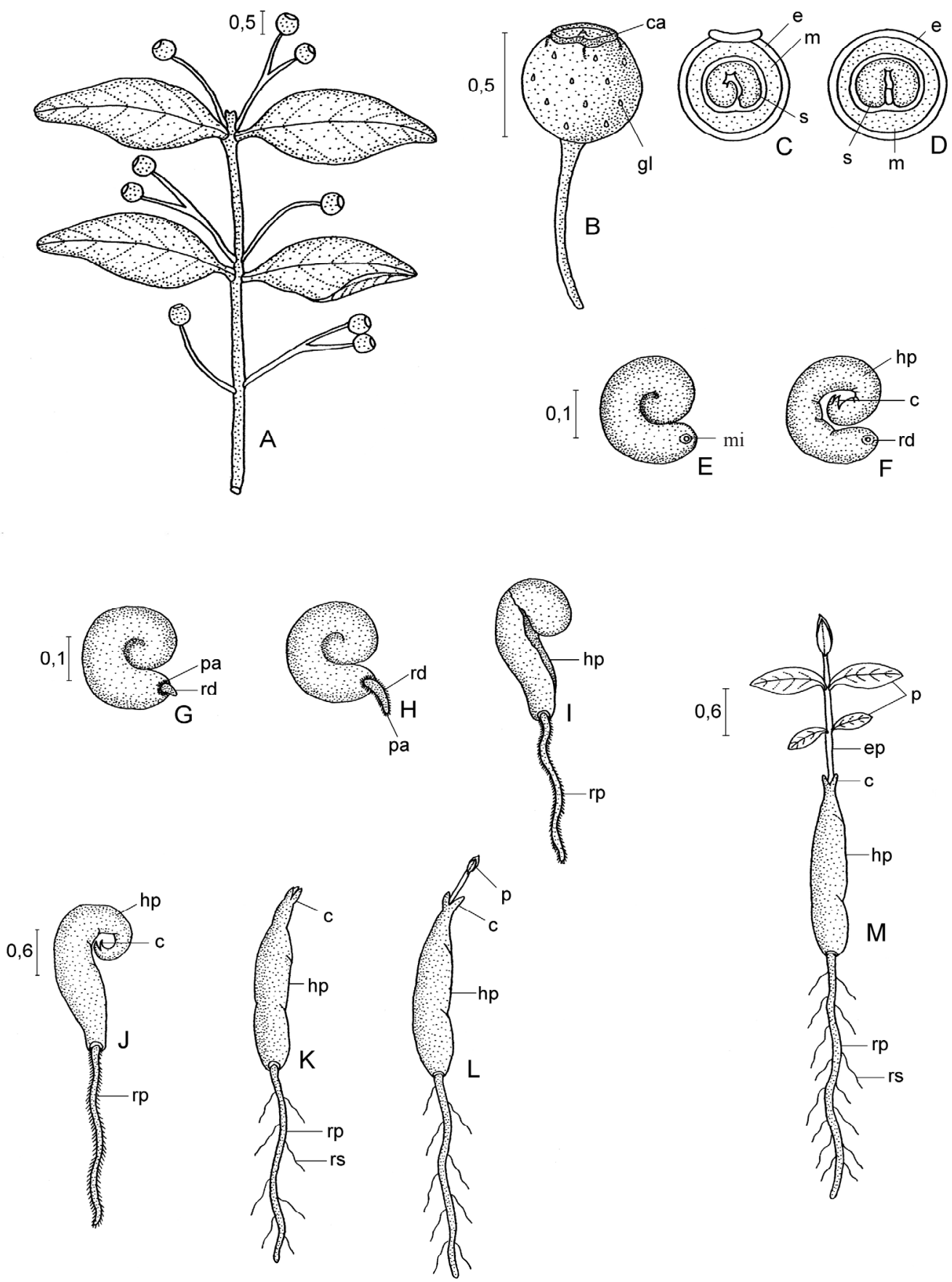

A - ramo com frutos, B - fruto, C - secção longitudinal do fruto, D - secção transversal do fruto, E - semente, F - embrião, G-M - fases da germinação e desenvolvimento da plântula, $\mathrm{c}$ - cotilédones, $\mathrm{ca}$ - cálice, ep - epicótilo, e - epicarpo, gl - glândulas, hp - hipocótilo, $\mathrm{m}$ - mesocarpo, mi - micrópila, $\mathrm{p}$ protofilos, pa - pêlos absorventes, $\mathrm{rd}$ - radícula, $\mathrm{rp}$ - raiz principal, $\mathrm{rs}$ - raízes secundárias, $\mathrm{s}-\mathrm{semente}$. Escala em $\mathrm{cm}$.

FIGURA 1. Fruto, semente, fases da germinação e plântula de B. salicifolius 
TABELA 1. Comprimento e diâmetro de frutos, número de sementes por fruto e comprimento, largura e espessura das sementes de Blepharocalyx salicifolius.

\begin{tabular}{|c|c|c|c|c|c|}
\hline Dimensões (mm) & Mínimo & Média & Máximo & Desvio padrão & $\begin{array}{c}\text { Coeficiente de variação } \\
(\%)\end{array}$ \\
\hline \multicolumn{6}{|c|}{ Frutos } \\
\hline Comprimento & 4,15 & 5,29 & 6,25 & 0,47 & 8,88 \\
\hline Diâmetro & 4,20 & 5,49 & 6,85 & 0,55 & 10,05 \\
\hline $\mathrm{N}^{\mathrm{o}}$ de sementes por fruto & 1,00 & 1,43 & 3,00 & 0,64 & 44,73 \\
\hline \multicolumn{6}{|c|}{ Sementes } \\
\hline Comprimento & 2,80 & 3,63 & 4,25 & 0,31 & 8,52 \\
\hline Largura & 2,05 & 3,13 & 3,75 & 0,33 & 10,51 \\
\hline Espessura & 1,35 & 2,19 & 3,10 & 0,39 & 17,70 \\
\hline
\end{tabular}

Semente: a semente (Figuras 1-E) possui forma de espiral, com base e ápice arredondados e uma reentrância lateral, possuindo em média $3,63 \mathrm{~mm}$ de comprimento, $3,13 \mathrm{~mm}$ de largura e $2,19 \mathrm{~mm}$ de espessura (Tabela 1). O tegumento é liso, membranáceo, de coloração castanha, semitransparente, permitindo a visualização do embrião verde escuro. A micrópila é visível e se localiza na base do hipocótilo (Figura 1-E). Não possui endosperma, e o embrião é do tipo hipocotilar (o eixo hipocótilo radícula desenvolvese bastante, enquanto os cotilédones são vestigiais), axial e invaginado. Os cotilédones rudimentares possuem a forma de duas asas membranáceas (Figura 1-F). De acordo com Barroso et al. (1999) nos embriões hipocotilares o eixo hipocótilo radícula constitui um órgão armazenador de reservas. Nestas sementes o embrião passa a ocupar toda a cavidade da semente (Souza, 2006). O embrião é de coloração verde escura e o hipocótilo e os cotilédones possuem glândulas por toda a superfície. De acordo com a classificação de Barroso et al. (1999) o embrião é do tipo pimentóide que se caracteriza pelo eixo hipocótilo radícula carnoso, curvo em forma de "C", ou em espiral, e cotilédones pouco desenvolvidos a vestigiais. Santos et al. (2004) verificou o mesmo tipo de embrião para Campomanesia guazumifolia, Campomanesia xanthocarpa e Psidium cattleyanum. Barroso (1984) descreve outros tipos de embriões, que são especializações dos três tipos citados por Barroso et al. (1999), e dentre estes o embrião de Blepharocalyx é classificado como uma forma mais especializada do embrião pimentóide: embrião crasso, enrolado em espiral, constituído pelo eixo hipocótilo-radícula, em cujo ápice localizam-se os cotilédones rudimentares.

Desenvolvimento da plântula: a germinação é epígea, fanerocotiledonar e inicia-se no $5^{\circ}$ dia se estendendo até o $50^{\circ}$ dia. A germinação inicia-se pela emissão da radícula na base do hipocótilo, na região da micrópila (Figura 1-G). A radícula é inicialmente densamente pilosa de coloração creme. A partir do $19^{\circ}$ dia o tegumento se rompe, devido a expansão do embrião que começa a desenrolar (Figura 1-I). No $35^{\circ}$ dia o embrião já está livre do tegumento, e a raiz com 2,0 cm de comprimento (Figura 1-J). O embrião se apresenta completamente desenrolado ao $45^{\circ}$ dia (Figura 9-K), e a partir do $50^{\circ}$ dia o epicótilo se expande e surgem os protofilos (Figura 1-L). No $70^{\circ}$ dia já se tem a plântula propriamente dita, com o primeiro e o segundo par de folhas abertos (Figura 1-M).

A raiz é do tipo axial, sinuosa e cilíndrica, de coloração creme, com raízes secundárias e poucos pêlos absorventes. O hipocótilo é carnoso, armazenador de reservas, de coloração verde escura e com glândulas na sua superfície. Os cotilédones são vestigiais, com a forma de duas asas membranáceas, são lisos, possuem glândulas e a coloração verde escura. $\mathrm{O}$ tipo de cotilédone presente em $B$. salicifolius não se enquadra nos três tipos citados por Vogel (1980) (armazenador, haustorial e paracotilédones), pois estes são rudimentares, e o órgão armazenador de reservas é o hipocótilo. De acordo com Vogel (1980) características específicas do hipocótilo e cotilédones como tamanho, coloração, forma e ornamentação são úteis na distinção entre espécies. Tais características do hipocótilo e cotilédones de $B$. salicifolius poderiam ser utilizadas para a distinção da espécie. O epicótilo é longo, verde claro, cilíndrico e coberto por pêlos. As primeiras folhas são simples, pecioladas, peninérveas, opostascruzadas, de consistência membranácea, lisas e com pêlos somente na face abaxial, mais densos na nervura principal. Possuem forma elíptica, a margem inteira, ápice agudo e base acuneada (Figura 1-M). 


\section{Myrceugenia gertii}

Fruto: os frutos (Figuras 2-A, B) são do tipo bacóide, carnosos, indeiscentes e globosos. Possuem de 1 a 8 sementes por fruto e em média $15,38 \mathrm{~mm}$ de comprimento e 13,21 mm de diâmetro (Tabela 2). O epicarpo é glabro, liso e passa pelas colorações verde, vermelha e roxa escura. O mesocarpo é farto e possui coloração laranja. O cálice é persistente nos frutos (Figura 2-B).

TABELA 2. Comprimento e diâmetro de frutos, número de sementes por fruto e comprimento, largura e espessura das sementes de Myrceugenia gertii.

\begin{tabular}{|c|c|c|c|c|c|}
\hline Dimensões (mm) & Mínimo & Média & Máximo & Desvio padrão & $\begin{array}{c}\text { Coeficiente de variação } \\
(\%)\end{array}$ \\
\hline \multicolumn{6}{|c|}{ Frutos } \\
\hline Comprimento & 11,20 & 15,38 & 21,00 & 1,72 & 11,17 \\
\hline Diâmetro & 10,10 & 13,21 & 18,10 & 1,38 & 10,41 \\
\hline $\mathrm{N}^{\mathrm{o}}$ de sementes por fruto & 1,00 & 2,58 & 8,00 & 1,37 & 53,18 \\
\hline \multicolumn{6}{|c|}{ Sementes } \\
\hline Comprimento & 1,0 & 7,77 & 9,50 & 1,21 & 15,56 \\
\hline Largura & 4,20 & 5,71 & 7,70 & 0,87 & 15,17 \\
\hline Espessura & 2,20 & 3,82 & 7,80 & 0,80 & 20,90 \\
\hline
\end{tabular}

Semente: as sementes (Figuras 2-C) são ovaladas, comprimidas lateralmente, com ápice e base arredondados, possuindo em média 7,7 $\mathrm{mm}$ de comprimento, $5,71 \mathrm{~mm}$ de largura e 3,82 $\mathrm{mm}$ de espessura (Tabela 2). O contorno do hipocótilo é visível externamente no tegumento, sendo este liso, membranáceo, de coloração castanha, semitransparente. A coloração verde do embrião também pode ser visualizada no tegumento. $\mathrm{O}$ endosperma é mucilaginoso e hialino, passando despercebido na semente seca, porém pode ser visualizado na semente no início da germinação. Barroso et al. (1999) verificaram entre as dobras dos cotilédones e entre as depressões da espiral do eixo hipocótilo-radícula de Myrceugenia sp. a presença de certa quantidade de uma substância que se tornou gelatinosa, quando hidratada, e verificaram a presença de açúcares e gotículas lipídicas nesta substância. O hilo e a micrópila são visíveis no tegumento da semente. O hilo é uma cicatriz deprimida de forma elíptica e de coloração laranja que se localiza na porção lateral da semente, acima da micrópila e esta se encontra na porção final do hipocótilo (Figuras 2-E, F). O embrião é do tipo cotiledonar (distinguem-se o eixo hipocótilo-radícula e os cotilédones), axial, invaginado, carnoso, de coloração verde-escura. Os cotilédones possuem coloração verdeescura, são foliáceos e fortemente dobrados, envolvidos um no outro. O eixo hipocótilo-radícula é longo, e possui glândulas por toda a sua superfície, formando uma espiral de duas voltas em torno dos cotilédones (Figura 2-G).
De acordo com a classificação de Barroso et al. (1999) o embrião de Myrceugenia gertii é do tipo mircióide: cotilédones livres, amplos, foliáceos, dobrados e com eixo hipocótilo-radícula longo, geralmente apressos a estrutura mais ou menos reniforme formada pelos cotilédones. No entanto, para Barroso (1984) a forma desse embrião lembra a do embrião mircióide e tem sido citada com esse nome, mas considerando suas características muito individuais, preferiu denominá-lo embrião mirceugenóide. Porém, esta classificação não é muito utilizada, sendo mais comum a denominação de embrião mircióide. Santos et al. (2004) e Kuniyoshi (1983) também verificaram a presença de embrião mircióide em Acca sellowiana e Myrcia arborescens.

Desenvolvimento da plântula: a germinação é epígea, fanerocotiledonar e inicia-se no $2^{\circ}$ dia se estendendo até o $8^{\circ}$ dia. A germinação tanto de $M$. gertii, quanto de $B$. salicifolius é considerada rápida segundo $\mathrm{Ng}$ (1978). De acordo com este autor esta rápida germinação de todas as sementes viáveis em um curto período de tempo é uma estratégia bem sucedida, mas ineficaz, pois as plântulas irão competir entre elas. Estas espécies estarão mais vulneráveis à extinção, pois são mais suscetíveis ao ataque de predadores e não possuem um estoque de sementes no solo. Este fato torna-se ainda mais preocupante para $M$. gertti, que já está na lista vermelha de espécies ameaçadas de extinção. 

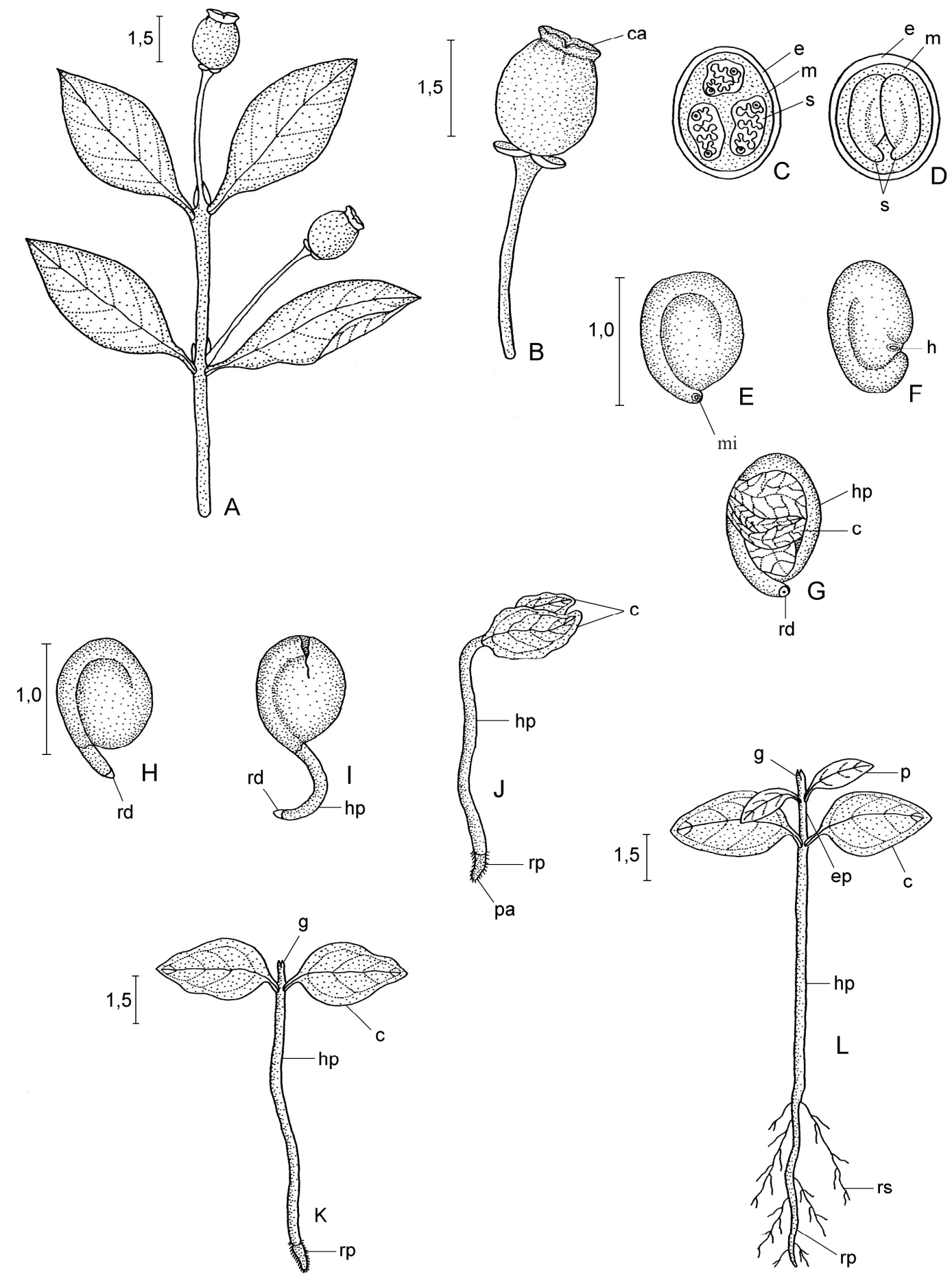

A - ramo com frutos, B - fruto, C - secção transversal do fruto, D - secção longitudinal do fruto, E - semente, F - vista lateral da semente, G - embrião, H-L - fases da germinação e desenvolvimento da plântula. c - cotilédones, ca - cálice, e - epicarpo, ep - epicótilo, g - gema, h - hilo, hp - hipocótilo, m - mesocarpo, mi-micrópila, pa - pêlos absorventes, $\mathrm{p}$ - protofilos, $\mathrm{rd}$ - radícula, $\mathrm{rp}$ - raiz principal, $\mathrm{rs}$ - raízes secundárias, $\mathrm{s}$ - semente. Escala em cm.

\section{FIGURA 2. Fruto, semente, fases da germinação e plântula de M. gertii.}

A emissão da radícula se dá pela porção final do hipocótilo, junto à micrópila (Figura 2-H). A radícula de coloração creme é inicialmente densamente pilosa, com os pêlos mais concentrados na região do colo. A partir do $4^{\circ}$ 
dia inicia-se o rompimento do tegumento devido à expansão do hipocótilo que começa a se desenrolar (Figura 2-I). O hipocótilo cilíndrico, reto e alongado eleva epigealmente os cotilédones ainda dobrados. Os cotilédones começam a se expandir aproximadamente no $8^{\circ}$ dia após o início da germinação, e são fortemente marcados pelas dobras (Figura 2-J). Aos 90 dias surgem as gemas dos protofilos (Figura 2-K), que estão expandidos aos 120 dias (Figura 2-L).

Na plântula, a raiz é axial, cilíndrica, sinuosa, de coloração castanho-clara, com pêlos radiciais inconspícuos e grande ramificação secundária. O hipocótilo é longo, cilíndrico, piloso, de coloração castanho-escura e recoberto por glândulas. O epicótilo é curto, piloso e de coloração verde-clara. Os cotilédones são foliáceos, peninérveos, de coloração verde-escura, com a superfície rugosa, de forma ovada a deltóide, com o ápice agudo e a base truncada e com a margem levemente ondulada. Vogel (1980) denominou este tipo de cotilédone de paracotilédones de acordo com a sua forma e função. Sementes que apresentam paracotilédones, como $M$. gertii possuem pouco ou não apresentam endosperma, pois a função de nutrir a plântula será realizada pelos paracotilédones através da fotossíntese (Vogel, 1980; Ng, 1978).

Os protofilos são simples, peciolados, verde mais claro que os cotilédones, peninérveos, de consistência membranácea, forma elíptica, com a margem inteira, ápice agudo e base acuneada, a filotaxia é oposta cruzada e a superfície é pilosa (Figura 2-L). As características dos protofilos são muito importantes na identificação de plântulas, pois geralmente o arranjo é específico. Em Myrtaceae quando as folhas adultas são opostas as folhas das plântulas também têm esse arranjo (Vogel, 1980). Outra característica específica é a presença de glândulas nas folhas adultas, que podem ser visualizadas em várias partes da plântula, como no hipocótilo, cotilédones e protofilos.

A plântula de $M$. gertii, é classificada como PEF (fanerocotiledonar, epígea, foliácea) de acordo com Garwood (1996), que classificou as plântulas em cinco tipos (PEF, PER, PHR, CHR e CER) conforme a exposição (fanerocotiledonar ou criptoradicular) e posição (epígea ou hipógea) da plântula e textura dos cotilédones (foliáceos ou de reserva). Já a plântula de $B$. salicifolius não se enquadra em nenhum, pois os cotilédones não são de reserva, nem foliáceos.

Santos et al. (2004) verificaram uma relação entre o tipo de embrião e a germinação em espécies de Myrtaceae, sendo que nos embriões do tipo mircióide a germinação foi epígea fanerocotiledonar, com os cotilédones atuando como folhas fotossintetizantes, fato este também verificado para M. gertii.

\section{REFERÊNCIAS}

AMORIM, I.L. de. Morfologia de frutos, sementes, germinação, plântulas e mudas de espécies florestais da região de Lavras - MG. 1996. 127f. Dissertação (Mestrado em Engenharia Florestal) - Universidade Federal de Lavras, Lavras, 1996.

BARROSO, G.M. Sistemática de angiospermas do Brasil. Viçosa: UFV, 1984. v.2. 377p.

BARROSO, G.M.; MORIM, M.P.; PEIXOTO, A.L.; ICHASO, C.L.F. Frutos e sementes: morfologia aplicada à sistemática de dicotiledôneas. Viçosa: UFV, 1999. 443p.

CARVALHO, P.E.R. Espécies arbóreas brasileiras. Colombo: Embrapa Florestas, 2006. v.2. 627p.

FAPESP. Programa Biota. Lista oficial de plantas ameaçadas de extinção no estado de São Paulo. Disponível em: $<$ http//www.biota.org.br>. Acesso em 10 ago. 2006.

GARWOOD, N.C. Functional morphology of tropical tree seedling. In: SWAINE, M.D. (Ed.). The ecology of tropical forest tree seedling. Paris: Unesco and Parthenom Publishing Grouo, 1996. p.59-129.

KUNIYOSHI, Y.S. Morfologia da semente e da germinação de 25 espécies arbóreas de uma Floresta com Araucaria. 1983. 233f. Dissertação (Mestrado em Ciências Florestais) Departamento de Engenharia Florestal, Universidade Federal do Paraná, Curitiba, 1983.

LANDRUM, L.R. A monograph of the genus Myrceugenia (Myrtaceae). New York: New York Botanical Garden, 1981, 132p. (Flora Neotropica Monograph, n. 29).

LANDRUM, L.R. Taxonomic implications of the discovery of calyptrate species of Myrceugenia (Myrtaceae). Brittonia, v.36, n.2, p.161-166, 1984.

LANDRUM, L.R.Campomanesia, Pimenta, Blepharocalyx, Legrandia, Acca, Myrrhinium, and Luma (Myrtaceae). New York: New York Botanical Garden, 1986, p.116-160. (Flora Neotropica Monograph, n. 45).

LANDRUM, L.R.; KAWASAKI, M.L. The genera of Myrtaceae in Brazil: an illustrated synoptic treatment and 
identification keys. Brittonia, v.49, n.4, p.508-536, 1997.

LEGRAND, C.D..; KLEIN, R.M. Mirtáceas. In: REITZ, P.R. Flora ilustrada catarinense. Itajaí: Herbário Barbosa Rodrigues, 1970. 453p.

LEGRAND, D.C.; KLEIN, R. Mirtáceas. v.17-22. In: REITZ, P.R. Flora ilustrada catarinense. Itajaí: Herbário Barbosa Rodrigues, 1978. 876p.

LORENZI, H. Árvores brasileiras: manual de identificação e cultivo de plantas arbóreas nativas do Brasil. 2.ed. Nova Odessa: Plantarum, 1998. 352p.

MARCHIORI, J.N.C.; SOBRAL, M. Dendrologia das Angiospermas: myrtales. Santa Maria: UFSM, 1997. 304p.

MORAIS, P.O.; LOMBARDI, J.A.A Família Myrtaceae na Reserva Particular do Patrimônio Natural da Serra do Caraça, Catas Altas, Minas Gerais, Brasil. Lundiana, v.7, n.1, p.3-32, 2006.

NG, F.S.P. Strategies of establishment in Malayan forest trees. In: TOMLINSON, P.B.P.; ZIMMERMANN, M.H. (Ed.). Tropical trees as living systems. London: Cambridge University Press, 1978. p.129-162.

OLIVEIRA, E. de. C. Morfologia de plântulas. In: AGUIAR, I.B. de; PIÑA-RODRIGUES, F.C.M.; FIGLIOLIA, M.B. Sementes florestais tropicais. Brasília, DF: ABRATES, 1993, p.175-213.

PARANÁ. Secretaria de Estado do Meio Ambiente. Lista vermelha de plantas ameaçadas de extinção no estado do Paraná. Curitiba: SEMA/GTZ, 1995. 139p.

RODERJAN, C.V. Morfologia do estágio juvenil de 24 espécies de uma Floresta com Araucária. 1983. 148f. Dissertação (Mestrado em Ciências Florestais) Departamento de Engenharia Florestal, Universidade Federal do Paraná, Curitiba, 1983.

SANTOS, C.M.R. dos.; FERREIRA, A.G.; ÁQUILA, M.E.A. Características de frutos e germinação de sementes de seis espécies de Myrtaceae nativas do Rio Grande do Sul. Ciência Florestal, v.14, n.2, p.13-20, 2004.

SILVA JÚNIOR, M.C. da. 100 árvores do cerrado: guia de campo. Brasília, DF: Rede de sementes do Cerrado. 2005. $278 \mathrm{p}$.

SOUZA, L.A. de. Anatomia do fruto e da semente. Ponta Grossa: UEPG. 2006. 200p.

SPJUT, W.R. A systematic treatment of fruit types. In: MEMOIRS OF BOTANICAL GARDEN, New York: The New York Botanical Garden, 1994, v.70. 182p.

VIDAL, W.N.; VIDAL, M.R.R. Botânica organografia: quadros sinóticos ilustrados de fanerógamos. Viçosa: UFV, 2003.124 p.

VOGEL, E.F. Seedlings of dicotyledons: structure, development, types descriptions of 150 woody Malesian taxa. Wageningen: Centre for Publishing and Documentation, 1980. 471p. 